\section{Intersections}

Canadian Journal of Music

Revue canadienne de musique
Intersections

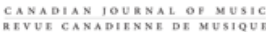

\title{
Performance Practice of Brian Cherney's Music: Interviews with Marina Thibeault, Julia Den Boer, and Paul Vaillancourt
}

\section{Aiyun Huang}

Volume 37, numéro 1, 2017

Illuminations: Essays in Honour of Brian Cherney

URI : https://id.erudit.org/iderudit/1059895ar

DOI : https://doi.org/10.7202/1059895ar

Aller au sommaire du numéro

Éditeur(s)

Canadian University Music Society / Société de musique des universités canadiennes

ISSN

1911-0146 (imprimé)

1918-512X (numérique)

Découvrir la revue

Citer ce document

Huang, A. (2017). Performance Practice of Brian Cherney’s Music: Interviews with Marina Thibeault, Julia Den Boer, and Paul Vaillancourt. Intersections, 37(1), 201-219. https://doi.org/10.7202/1059895ar
Résumé de l'article

La composition et l'interprétation de la musique du compositeur canadien Brian Cherney sont mises en contexte au moyen d'entrevues avec l'altiste Marina Thibeault, la pianiste Julia Den Boer et le percussionniste Paul Vaillancourt. Ces trois musiciens ont interprété des oeuvres importantes de Cherney pour Illuminations: Brian Cherney at 75 visant à célébrer l'oeuvre et la vie du compositeur. Ils analysent tous les trois les défis que posent les partitions de Cherney et discutent des formes d'inspiration qu'ils ont trouvées dans l'interprétation de sa musique.
Copyright @ C Canadian University Music Society / Société de musique des universités canadiennes, 2019
Ce document est protégé par la loi sur le droit d'auteur. L’utilisation des services d’Érudit (y compris la reproduction) est assujettie à sa politique d'utilisation que vous pouvez consulter en ligne.

https://apropos.erudit.org/fr/usagers/politique-dutilisation/ 


\title{
PERFORMANCE PRACTICE OF BRIAN CHERNEY'S MUSIC: INTERVIEWS WITH MARINA THIBEAULT, JULIA DEN BOER, AND PAUL VAILLANCOURT
}

\author{
Aiyun Huang
}

\section{INTRODUCTION}

I had the honour and pleasure of hosting "Illuminations: Brian Cherney at 75" to celebrate the music and scholarly work of the Canadian composer Brian Cherney. My role as the main organizer included preparing the successful grant application, and conference planning and production, as well as performing in the last of three concerts of his music. I want to take this opportunity to acknowledge the tremendous help I received from my team: Matthew Ricketts (conference planning, production, and publicity), Taylor Brook (SSHRC Connection Grant application), Noam Bierstone (concert production), Jess Tsang (reception), David Rafferty (documentation), Sara Gomez (website), Zosha Di Castri (programming), Eightie Trois (booklet design), and Robert Del Tredici (photography).

The conference program resulted from the combination of team curation (Cherney, Brook, Di Castri, Ricketts, and Huang) and a vigorous selection process by seven reviewers. The organizational team chose the repertoire for Concert No. 2 and Concert No. 3 based on the goal of presenting a wide selection of repertoire representing Cherney's diverse compositional output. Repertoire presented in Concert No. 1 was selected through a peer-review process.

Concert No. 1:

- Gan Eden (1983) for violin and piano (performed by Wapiti Ensemble)

- Doppelgänger (1991) for two flutes (performed by Claire Marchand and Marilène Provencher-Leduc)

- Shekhinah (1988) for solo viola (performed by Marina Thibeault)

Concert No. 2:

- String Quartet No. 3 (1985) (performed by Molinari Quartet)

- Twenty-two Arguments for the Suspension of Disbelief (2010) (performed by $\mathrm{Nu}: \mathrm{BC}$ )

- Like Ghosts from an Enchanter Fleeing (1993) (performed by Chloé Dominguez and Jean Marchand) 
- String Trio (1976) (performed by Joshua Peters, Marina Thibeault, and Carmen Bruno)

Concert No. 3:

- Seven Images for Twenty-two Players (1971) (performed by the McGill Contemporary Music Ensemble)

- Tombeau (1996) (performed by Julia Den Boer)

- In Gottes Gärten schweigen die Engel (2006; revised 2017) (performed by the McGill Percussion Ensemble with Paul Vaillancourt and Jessica Gauthier)

- Playing for Time (1981) (performed by Kyoko Hashimoto, Aiyun Huang, Jacqueline Leclair)

This article addresses the performance practice of Cherney's music, as contextualized through interviews with three performers-Marina Thibeault, Julia Den Boer, Paul Vaillancourt-who took on the most challenging repertoire in the symposium. At the end of the article, I also discuss my own perspective on performing Cherney's music. I chose these three interviewees for the article on the basis of the instrumental groups they represent-strings, piano, and percussion-as Cherney wrote extensively for these instrumental groups. Together, the three interviewees present a contrasting, broad, and in-depth view on how to play Cherney's music, how to develop an interpretation, and how to relate his compositions to their respective instrumental performance practice. Furthermore, I chose these three performers for the time and dedication they have devoted to championing Cherney's music. Marina Thibeault performed the monumental Shekhinah for solo viola and played in the String Trio during the symposium; Julia Den Boer performed a twenty-five-minute piano solo, Tombeau; and Paul Vaillancourt performed a percussion concerto, In Gottes Gärten schweigen die Engel. These interviews took place in the weeks after the conference.

Before I begin this discussion about the performance practice of Cherney's music, I must first acknowledge that his music is not frequently performed. Although there were no premieres in the symposium, for many of us who attended the concerts it was the first time we had the chance to hear this repertoire. Prior to hosting and participating in the symposium, I knew only Cherney's percussion works and had performed only two of his pieces. For most people who attended the symposium, including colleagues who have studied and written about Cherney's music, it would have been their first time hearing most of the pieces presented in live settings. Several presenters spoke on the topic of Cherney's String Trio from 1976 and regard the work as one of the best string trios ever written in the twentieth century. However, according to Cherney himself, the trio of Peters, Thibeault, and Bruno was only the fourth group to take on the challenge of truly learning the piece.

This is an interesting issue to me, as a performer who has dedicated a large part of my career to championing new music. Performers often struggle with the balance between promoting new music (i.e., premieres) and championing existing repertoire. Inevitably much interesting, worthy music is left behind as 
we look for the next great work. Given the scarcity of Cherney advocates, the topic of performance practice of his music needs to be examined through the lens of the larger musical movements of the twentieth and twenty-first centuries to which his work is technically and spiritually allied. Perhaps when we think about Messiaen, we are in fact getting closer to describing what it is like to perform Cherney's piano music. By considering European avant-garde composers such as Ligeti, Xenakis, and Kagel, we can perhaps get a clearer sense of where Cherney comes from, and more importantly, how to develop an interpretative context for the performance and performance practice of his music.

\section{Preface to the Interview with Marina Thibeault}

Marina Thibeault, a doctoral student at the Schulich School of Music in McGill University, performed two pieces, Shekhinah and String Trio, in the conference. This was her first experience performing Cherney's compositions, and she was immediately drawn to the music. As an emerging artist with an interest in championing Cherney's music, Thibeault brings the possibility of renewal to this repertoire.

\section{Shekhinah (Program Note by Brian Cherney)}

On March 19, 1988, the Montreal Gazette published a review of a new book, The Holocaust in History (Marrus 1987), by the University of Toronto historian Michael Marrus. Accompanying this review was a photograph of a procession of Jewish women and children. I subsequently learned that the photograph was, in fact, taken at Auschwitz in May 1944 and that the people were Hungarian Jews. Since the children in the photograph were too young to work, it is likely that these people all perished in the gas chambers and crematoria of that concentration camp. My attention was particularly drawn to one of the women in the photograph-a striking figure with a shawl over her head, taller and younger than most of those around her. Her bearing and facial features reminded me, in an uncanny way, of the violist Rivka Golani, for whom I was about to write a work for unaccompanied viola. The idea then occurred to me to write a work for that woman in the photograph, dedicated to her memory. I hoped thereby, in some small way, to rescue her from anonymity and oblivion.

The viola piece entitled Shekhinah was written in April and May of 1988 and was revised in March and April of 1989. The Hebrew word "Shekhinah" is generally understood to refer to the feminine aspect of the deity. In Major Trends in Jewish Mysticism, Gershom Scholem points out that this early concept of the Shekhinah (as the feminine element in God) later developed into a concept of the Shekhinah as a symbol of "eternal womanhood ... representing the mystical idea of Israel in its bond with God and in its bliss, but also in its suffering and its exile."

Shekhinah is dedicated to the memory of the woman in the photograph. (Cherney 2017) 


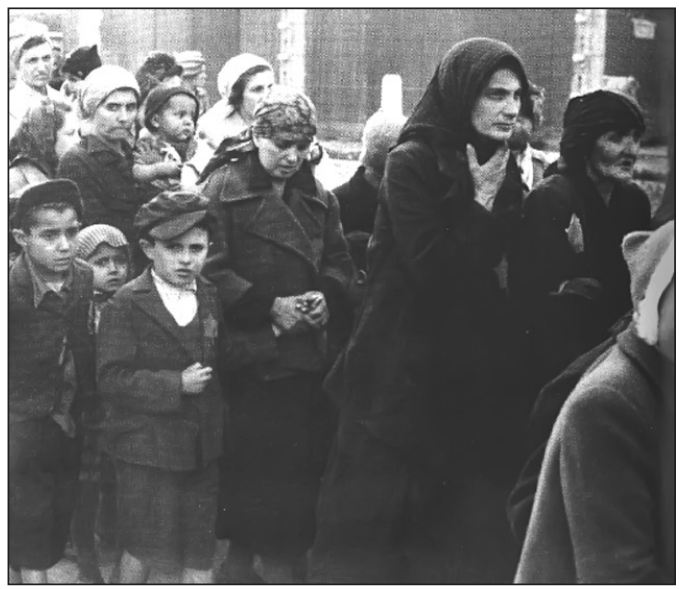

Figure 1. The woman to whom Shekhinah is dedicated (Rodal 1988)

\section{Conversation with Marina Thibeault ${ }^{1}$}

Aiyun Huang. Can you tell us a little about yourself, where you are in terms of the kind of music you want to pursue in general?

Marina Thibeault. My love for new music emerged when I was a part of the 20/21 ensemble at the Curtis Institute. It included a composer residency program, so I got to work with Joan Tower, Penderecki, Corigliano, and that is when I really took part in and enjoyed working with living composers. After I graduated from Curtis, I continued to look for those experiences. I had a few works written for me, including one by Jean Lesage, and I did the premiere recording of Ana Sokolovic's Prelude. I also have commissions underway including concerti by Taylor Brook and Jeffrey Mumford. I am very active in new music, especially as a violist, because this is the future of my instrument as a solo voice. There is still a lot of music that needs to be written, and it is very interesting for me to collaborate with composers in order to help develop the viola as a solo instrument.

HUANG. What were your inspirations from the viola world?

Thibeault. Without a doubt Rivka Golani did so much for our instrument, collaborating with Canadian composers, especially in the 1970s when the instrument was yet to be discovered in Canada as a solo instrument. At that time, there were great violists already in Europe, such as Yuri Bashmet, Tabea Zimmermann, and Kim Kashkashian. Rivka was a pioneer in North America and as a woman performer. So for me to play Shekhinah by Brian Cherney was a way to honour not only the amazing piece and Brian's work, but also to honour the first lady (Rivka) of the instrument in Canada. Rivka has performed the piece a few times and Douglas Perry has performed the work once. I am the third performer to take it on and I really hope to play it a lot more because it really is an incredible work.

\footnotetext{
1 Interview with Aiyun Huang, 14 November 2017, transcribed by Louis Pino.
} 
HUANG. Tell us about your experience working on the piece. I know it is an incredible work; it is one of the pieces of which Brian is most proud. Can you describe a little bit about what is so engaging about the piece? And what are some of the challenges? I am sure there are some technical challenges; there is also the challenge that the piece is quite long and elaborate.

Thibeault. When I was researching what Cherney has written for the viola, I discovered that there are quite a few works. Cherney didn't write only for Riv$\mathrm{ka}$, but also wrote for family members who are also violists. So there was a lot to look at. When I read the program notes of Shekhinah, it really touched me that Brian's inspiration came from a photo of a woman in Auschwitz published in the Montreal Gazette newspaper. According to Cherney, there is something so strong about the face of this woman, strong yet anonymous, which inspired the work. Although the piece was written for Rivka, it is really written for the woman in the photograph, to honour this woman whom nobody knows and probably did not survive. When I first read the piece I was nine months pregnant, I was overdue waiting for my baby to come. Not having met my child yet, I could not imagine what this woman was going through, knowing what would happen to her moments after this picture was taken. So there was a lot of anxiety, pain, and horrendousness that accompanied my learning of the piece.

The most challenging aspect of the work was the emotional baggage that it came with, so for a long time I put that away in the back of my mind. I was just doing the cooking, learning the notes and the rhythms. There is quite a lot on the page. The piece is very demanding technically, and there are many beautiful moments that are very vulnerable, and of course you do not want your bow to shake, you do not want your voice to crack, you want to be comfortable, but it is the most uncomfortable thing ever. So that was really challenging, but really the emotional aspect of the piece was a disguise I did not want to wear. I did not want to become this woman, yet as a musician you have to get deep in the piece to do the character properly. Right before the performance, I was really asking the Shekhinah, the divine female avatar in the Jewish religion, to help me, because I knew it was going to be difficult to be that vulnerable in front of people. In the performance, my iPad pedal did not work, so the technical glitch actually really helped me to let go and just be this anonymous woman.

HUANG. In your mind, the violist is in fact channelling the woman you see in the picture?

Thibeault. Yes, especially with all the anxiety at the beginning of the piece and all the "Death and the Maiden" quotes in the middle, and the really heavenly ending; for me it was really a rite of passage of this woman's soul. That is how I interpreted the piece. Cherney left me a lot of freedom, but he points out the anxiety in the music in the beginning, which I was trying to avoid. Rivka got this really well on the recording; you almost get a panic attack just listening to her. So that is what Brian and I discussed. It is amazing to play this piece with the composer in the room. I know he is very proud of this piece, as he should be. 


\section{Preface to Discussion of the String Trio}

Joshua Peters, Marina Thibeault, and Carmen Bruno performed the String Trio (1976) in Concert No. 2. This piece was actually the work that brought Cherney onto the international stage. It was a CBC commission and it gained him a lot of international recognition through the International Rostrum of Composers in Paris. It tied for first place in the "recommended" works in 1979. Otto Armin, violin, Rivka Golani, viola, and Peter Schenkman, cello premiered the work. According to Cherney, he feels "much indebted to these performers for their sympathetic and convincing rendition of the piece." Cherney describes the trio as follows in his program note for the piece:

The opening of the work, with its sustained open-string fifths and pizzicato figures, serves both as a point of departure and as a refrain, from which several other kinds of music emerge over the course of the work. In the early part one of these types involves some intense and highly virtuoso passages in which the instruments are more or less independent of each other-as if three strong-willed and passionate individuals were carrying on a fierce debate simultaneously. Another type to emerge is a rather sad fragment of tonal music (not a quotation!) which appears suddenly for the first time during the violin's cadenza and gradually becomes more fragmented with each subsequent appearance. It is this passage with which the piece concludes.

The general shape of the work is a progression from virtuoso playing - fast and intense-to a more subdued and introspective mood at the end. As part of this progression, I imagined each instrument to have undergone a kind of change of identity towards the end: the violin becomes flute-like in nature, the viola, like a French horn, and the cello, like a drum (for instance, the steady pizzicato $D$ at the very end). Each instrument has a kind of accompanied cadenza during the course of the piece. Those of the cello and violin overlap approximately in the middle, while that of the viola appears at a later stage and is a part of the transition towards the quieter mood of the latter part of the piece. It will be noted that the Trio contains several references to the Symphonies nos. I and VI of Mahler. At the end of the score, I have quoted a short passage from T.S. Eliot's poem "Portrait of a Lady":

Among the windings of the violins

And the ariettes

Of cracked cornets

Inside my brain a dull tom-tom begins

Absurdly hammering a prelude of its own,

Capricious monotone

That is at least one definite "false note."

The String Trio was dedicated to my father on the occasion of his sixtieth birthday in December 1976. (Cherney 2017) 


\section{INTERVIEW With MARINA ThibeaUlT}

Thibeault. I think that the Trio is probably one of the best chamber music experiences I have had-new and old music altogether. When you really get to love a piece, you do not see the background or the ethnicity of the composer, you just see music, and that is when you encounter a great composer.

HUANG. Although this piece is recognized as great music, it has not been performed much. We could go on guessing why the piece is not played more, but I am not sure that is pertinent to this discussion. I would like to understand more about the specifics of its special place in chamber music, and, for example, the notation and the process of creating your version.

Thibeault. Yes, we have to read from the score because there is a lot of aleatory writing and many cadenzas. It is not just helpful to play from the score; you need to play from the score. There are moments that need to be connected and moments that require complete freedom without getting lost.

This piece got a lot of recognition at the time because the string trio repertoire is not as rich as the string quartet, and the piece is a strong contribution musically and viscerally. I hope to decorate my new house with the score because each page is so absolutely gorgeous to look at as a piece of notational art. Musically, the voyage of performing the trio is like playing the Goldberg Variations or a Schubert quartet. It is rare to encounter this type of experience in new music. It is simply amazing!

HUANG. What are the challenges of the work in terms of a piece of chamber music?

Thibeault. You need to work out all the free sections so that there is some organized feel to it. There are a lot of notes that happen quickly so you have to be so comfortable with your own part that you can look at the other parts, because eventually you will have to link up with the other players. There is a lot of muscle memory involved, so you almost need to know your part by heart while busy looking at other parts. A lot of personal preparation is required. In addition, because you are playing with such humongous scores, the group needed to talk about the visual presentation. We almost had to use three stands each. It is a small detail, but we talked a lot about what we would do with page turns. Finally, we decided to use only one stand for aesthetic reasons. We had to think collectively and not just individually, so that when we would turn our pages there is always musical continuity. That was actually a big part of our preparation.

HUANG. How many hours did the three of you spend working on the piece?

Thibeault. So much, I don't think we counted, maybe fifty hours counting personal prep. As a group for sure we put in at least twenty hours. It didn't feel like too much.

Huang. And now you have played two of Brian's most important pieces. You are probably one of the few people who have actually had this kind of experience. Are there other pieces you think you may want to play in the future?

Thibeault. Yes, a few pieces that I would like to play with piano. Also, there is the Chamber Concerto for Viola and Ten Players that I am actively trying to program. This piece was only played once. It does not require a big orchestra, 


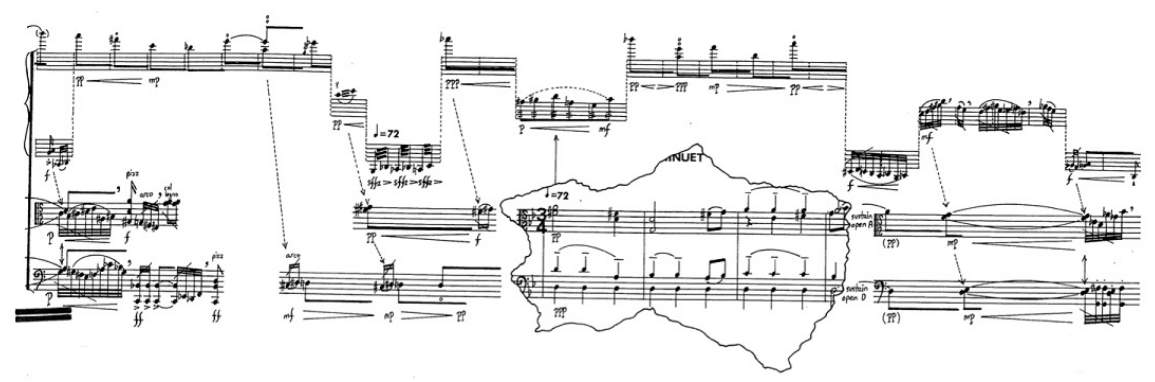

Figure 2. Excerpt from String Trio (p. 7, first system)

so I hope it gets played eventually and very soon. Shekhinah will follow me for a long time in all of my solo programs. There is a project that I am working on to play in women's shelters with the goal to honour women. Because of its background and the inspiration behind the work, Shekhinah will be a part of this program.

\section{Preface to the Interview with Julia Den Boer}

In Illuminations Julia Den Boer performed Tombeau (1996), a twenty-fiveminute piano solo dedicated to Cherney's friend Martin Bass, who passed away in the summer of 1996 at the age of fifty-four. Bass and Cherney were close friends since childhood so Cherney wrote this piece dedicated to the life of this wonderful physician, friend, husband, and father. (See pp. $72-78$ for Zosha Di Castri's discussion of Tombeau.)

\section{INTERView With JUlia Den Boer ${ }^{2}$}

Aiyun Huang. Was this the first time you performed a work by Cherney? If not, what were your previous experiences?

Julia Den Boer. I first performed music by Brian Cherney in the winter of 2017 at the Banff Centre. I was presenting new works by Zosha Di Castri and Matthew Ricketts, and they suggested I include a piece by Cherney in the program. I already had an interest in Tombeau but decided In the Stillness of the Seventh Autumn would be an interesting way to make myself familiar with his work and piano writing. Having gone to McGill and played a lot of music by students of Cherney, it was a very interesting experience to go back and discover his influence more in depth.

HUANG. I know that you spent some time selecting the piece when we were working on programming for the symposium. Can you please tell us why you selected Tombeau? What other pieces were you looking at?

Den Boer. Having already played In the Stillness of the Seventh Autumn, I was very interested in working on a larger scale work, and I felt Tombeau was ideal. Tombeau was written ten years after In the Stillness and I was interested in seeing the development of Cherney's style and piano writing. I considered

2 Recorded through email exchanges, 14 and 20 November 2017. 
performing Dans le crépuscule du souvenir, but the more personal and introspective qualities of Tombeau drew me to the work.

Huang. How would you describe the piece? I know that it has multiple movements. How are the movements different, for example? Are they all going after different things?

Den Boer. Tombeau is in seven movements: I. Prologue; II. Scherzo I; III. Interlude I; IV. Portrait; V. Interlude II; VI. Scherzo II; VII. Epilogue. The piece is an homage to Brian Cherney's close friend Martin Bass. The work is centred upon the fourth movement, Portrait, and structured around a motif based on the letters of his name [MART-in BASS becomes E, A, D, B, Bb, A, Eb, $\mathrm{E}^{b}$ ]. The piece has some very virtuosic moments, which Brian Cherney said he felt compelled to write at the request of the pianist Marc Couroux, who premiered the piece. It is a shift from his usual writing but extremely interesting how he manages to create a feeling of stillness, even through very dense textures and swiftly moving passagework in the two scherzi. The movements are contrasting, but there are recurring elements (bell-like chords, descending chord motif) throughout the piece, which makes it very cohesive.

HUANG. If you were to place the work in a lineage with other piano works, how would you describe its possible influences? In some clear ways, I hear Debussy (descending clusters, for example) and Messiaen (bell-like, cross-registered chords). Is that fair to say? How would you describe it for those who might not have a chance to hear the piece in performance?

Den Boer. I definitely hear the influence of Messiaen in the block-like texture of the beginning and these voices moving in completely independent temporalities. The slower movements are indeed more "impressionistic" in their texture and colours, but the extreme independence of the different layers almost draws the comparison to Ligeti or Xenakis; Cherney's music has a much more lyrical quality, though.

HuANG. What were the unique challenges to Tombeau? I had the pleasure of turning pages for you during the concert and I can remark on the challenges of reading multiple staves, running lines in two hands of different pitches and patterns, and multiple lines of material with overlapping registers as starting points. I am sure that there were other challenges that I missed.

Den Boer. The hyper-layered aspect of the piece makes it challenging. Some of the voices move extremely slowly and it is difficult to keep a sense of polyphony at times. It also is challenging to not make things too muddy when there are so many simultaneous levels of activity in the same register; voicing decisions are crucial in this piece. The general pace is also very slow, aside from the scherzi, which makes it a challenge for the performer to keep a sense of unfolding drama and to convey the arch-like form of the piece. On a more anecdotal note, the opening is written on six staves for the sake of highlighting the three different voices; it is indeed very difficult to read!

HuANG. As new music specialists, part of what we do is find meaningful connections to the score so that we can bring something personal to the stage. What were the special moments in the piece that allowed you to establish a 


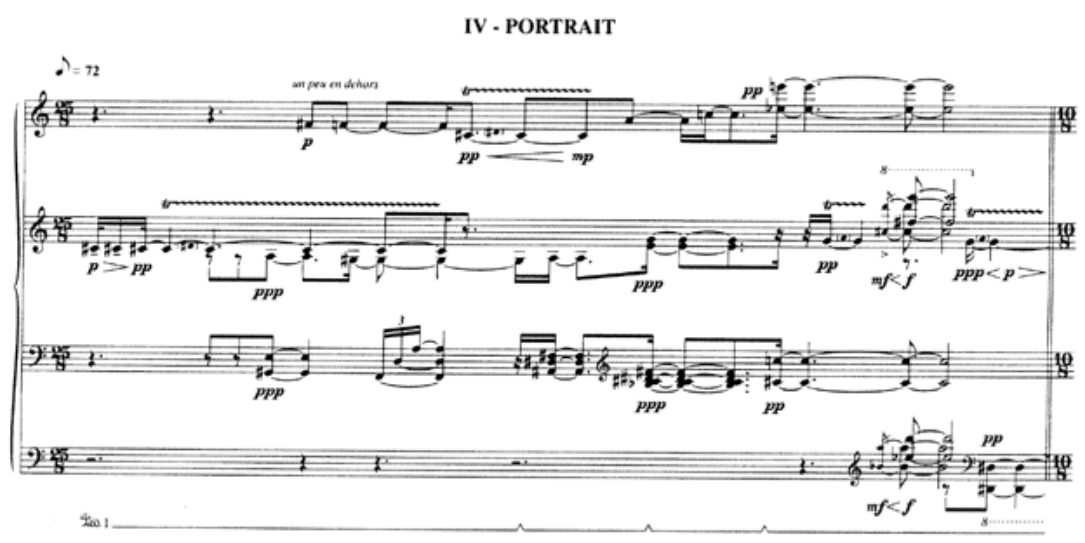

Figure 3. Portrait, movement IV from Tombeau (bar 1)

personal connection to the work and helped you with forming your beautiful interpretation?

Den Boer. Finding the lyrical qualities in the lines, doing so beyond a very detailed rhythmical notation, and making them your own is important in the process of learning the score. Even though the notation is very detailed, what makes the interpretation is internalizing it. The piece is so contrapuntal that there are also many personal decisions to be made about which voice is going to be in the foreground, or even sometimes making the decision that the voices should be treated in an equal manner. It is a really interesting process and I think this also helped me differentiate the movements from one another.

The second scherzo is interesting to me. I worked on trying to create an ethereal texture out of the passages. Finding the inner peace to play this movement while focusing on the slow-moving voice without the whole becoming frantic was a challenging process. It is almost like finding stillness in extreme motion!

\section{Preface to the Interview with Paul Vaillancourt}

Paul Vaillancourt performed In Gottes Gärten schweigen die Engel (2006; revised 2017) with soprano Jessica Gauthier and McGill Percussion Ensemble in Concert No. 3. As a long-time collaborator with Cherney and champion of his music, Vaillancourt has performed most of Cherney's music for percussion. In Gottes Gärten schweigen die Engel was first composed as a concerto for percussion solo and percussion ensemble in 2006. Cherney revised the piece in 2017 adding a soprano part featuring Rilke's poem "Die Engel." 


\section{Die Engel (1918)}

Sie haben alle müde Münde und helle Seelen ohne Saum.

Und eine Sehnsucht (wie nach Sünde)

geht innen manchmal durch den Traum.

Fast gleichen sie einander alle; in Gottes Gärten schweigen sie, wie viele, viele Intervalle in seiner Macht und Melodie.

Nur wenn sie ihre Flügel breiten, sind sie die Wecker eines Winds als ginge Gott mit seinen weiten Bildhauerhänden durch die Seiten im dunklen Buch des Anbeginns.

Rainer Maria Rilke, Das Buch der Bilder, 1906

\section{The Angels}

They all have tired mouths and bright seamless souls. And a longing (as for sin) Sometimes haunts their dream.

They are almost all alike; in God's gardens they keep still, like many, many intervals in his might and melody.

Only when they spread their wings are they wakers of a wind: as if God with his broad sculptorhands leafed through the pages in the dark book of the beginning.

transl. Edward Snow (Rilke 2009)

\section{Interview with Paul Vaillancourt ${ }^{3}$}

AIYUn HUANG. I know that you are a long-time collaborator with Cherney and have championed the majority of his percussion works (probably mostly in chamber music settings). Can you please tell us how you started working with Brian?

Paul Vaillancourt. The funny thing is I never worked with Brian while attending McGill for my master of music degree. Several years later I was directing the graduate Contemporary Chamber Players (CCP) at State University of New York, Stony Brook, while working on my DMA and organized a concert of music by Canadian composers, which included Brian's Die klingende Zeit (1993-94), Gilles Tremblay's Champs I, John Rea's Blues d'Orphée, and Steven Gellman's Chiaroscuro. I organized a tour of the group to several universities in the NYC area, up through SUNY Albany, then Montreal and Ottawa. We first met when Brian was able to come to the dress rehearsal at the Université de Montréal and attended the concert. Brian seemed very happy with the performance, which led to many future collaborations, the first being Entendre marcher un ange ... , a duo for flute and percussion written for my wife, Andrée Martin, and me. This was written in 1998 for our doctoral recitals at SUNY Stony Brook. We have also performed it at numerous festivals across the United States, Banff, for Radio-Canada in Ottawa, and Sound Symposium in Newfoundland.

Soon after this tour, Brian was commissioned for the Premieres Concert as part of the CCP season at SUNY Stony Brook the following year, which resulted in Shadow Dancing at Half-Past Nine (1999) for flute/alto, clarinet/bass, violin, cello, and percussion. It was very well received and was included as part of a short residency later that year, which also included a performance of the trio Playing for Time (1981) for percussion, piano, and oboe. 
Andrée and I both got teaching positions in Columbus, Georgia, in 2000 and organized a residency for Brian in 2006. The program included several premieres: Une petite histoire de gestes (2006) for two percussionists, which I premiered and recorded during the residency with percussionist D'Arcy Gray; The Return of Ulysses (1992) for alto saxophone; and Incantation (1999) for solo flute, which Andrée performed.

The residency also included a performance of In the Stillness Between (1982) for wind ensemble and the premiere of In Gottes Gärten schweigen die Engel (2006) for solo percussion and percussion ensemble, which was commissioned by the Carson McCullers Center for Writers and Musicians here in Columbus specifically for this residency. We recorded this work and released it on the CSU Percussion Ensemble's CD entitled Shifting Cells.

I was able to have Brian return to Columbus for another weeklong residency in 2015. This residency included a performance of La princesse lointaine (2001), a double concerto for English horn and harp, with the Columbus State University Philharmonic conducted by Paul Hostetter; faculty soloists were Susan Tomkiewicz, English horn, and Susan Bennett Brady, harp. We also presented a faculty chamber music concert of the following works:

Like Ghosts from an Enchanter Fleeing (1993), Wendy Warner, cello; Alina Sarkisyan Bennett, piano

Entendre marcher un ange ... (1998), Andrée Martin, flute; Paul Vaillancourt, percussion

In Time's Wake (2013), world premiere, Susan Tomkiewicz, oboe; Tatiana Muzanova, piano

Shadow Dancing at Half-Past Nine (1999), Lydia Carroll, flute; Max Frank, cello; Diana Sharpe, percussion; Boris Abramov, violin; Lisa Oberlander, clarinet; Paul Vaillancourt, conductor

HUANG. What are some of the unique challenges in Brian's music?

Vaillancourt. For a percussionist, Brian's music is difficult from a logistical standpoint. Percussion parts, though very clearly written and conceived, are never written with a specific set-up in mind. It can take a lot of experimentation to develop a set-up that will work for the entire piece and not just specific passages. The set-up for In Gottes Gärten schweigen die Engel, for example, took quite awhile to finalize, as instruments were being introduced throughout the piece, necessitating a continued change in the physical positioning of instruments during the learning process. The physical spatialization of these set-ups also make it very difficult for a performer to read the score and therefore requires memorization. The cadenzas from In Gottes ... are a great example of this. Kinesthetic memory must develop slowly over time to learn the physical layout of the instruments, which do not adhere to any previously learned setup. In effect, the set-up becomes an entirely new instrument that has to be learned from scratch. Finding mallets that speak evenly on all instruments is another challenge. Many instruments such as gongs, Noah bells, prayer bowls, 
marimbas, and vibraphones respond differently to the same stroke and require constant adjustments to create balance in a line or passage, and blend with other instruments.

HUANG. I concur with your observation about the challenge of logistics. I felt this strongly when I was working on In Gottes ... . As Brian wrote the piece specifically with your personal collection of sounds in mind, it was hard for me replicate that world of sonic possibilities without some replacements. Finding the right sounds for the piece took as much as time as learning the music-and finding the right set-up accounts for half of learning the music.

I know that we all feel a certain kinship towards certain composers. Why is Brian's music so special to you? Is it Brian's music that attracted you or his quirkiness and humour towards music and life?

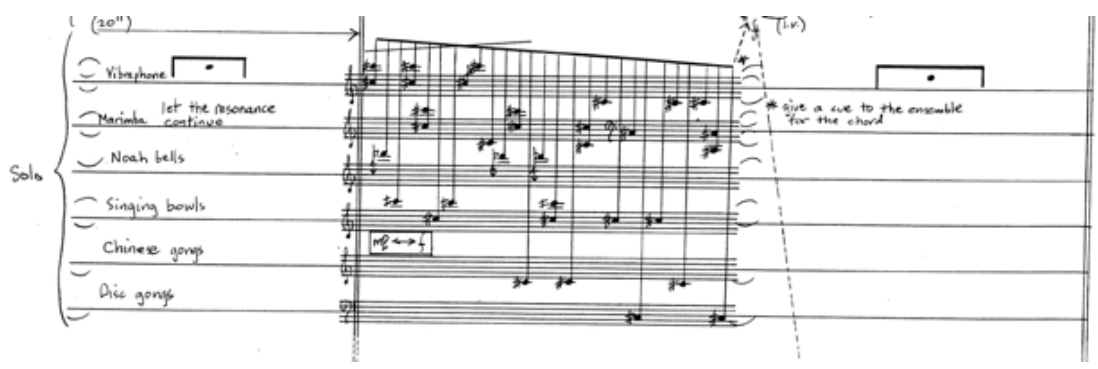

Figure 4. Cadenza figure from In Gottes Gärten schweigen die Engel, p. 22

VAILlAnCourt. Brian's music is very special to me on many levels. I greatly appreciate the craft, organization, and structure of his music. Something about the way his pieces are constructed resonates with me in a natural, intuitive way, even though, intellectually, I know they are highly organized on both macro and micro levels. Secondly, his use of percussion instruments and the wide palette of sounds and timbres his music requires is never superficial or clichéd. Often specific instruments and timbres are important for their role in delineating form, or themes or characters from a program, either from a poem or a play. The flute and percussion duo Entendre marcher un ange ... is a great example of this.

For me, Brian's music transcends the act of composition, providing performers a rare opportunity to prepare works that speak to the human condition and experience. His music is meaningful, yet technically very difficult. This struggle that all performers wrestle with when preparing one of his works is what makes the end result so dramatic and meaningful. As in life, all good things never come easy.

HuANG. May I interject here to say that the technical difficulty in Brian's music is not always apparent upon first glance when one opens the score! What about the other levels?

VAillancourt. On a very personal level, Brian's use of timbre, pacing, and exploration of sound is the other reason why his music speaks to me so deeply. Practising his music, such as In Gottes ... and Entendre ... I have to reacquaint 
myself with the physical kinesthetic layout of each piece, requiring slow, methodical, and repetitive practice. Practice sessions often become meditations, providing opportunities for introspection and reflection.

HuANG. Tell us about your collaborative process in making In Gottes ... . I know that Brian composed it especially for your unique collection of percussion sounds. How many times have you played the piece? I also know that Brian added a vocal part to the new version for the latest performance during the symposium. How does that change the piece? It is now a piece for two soloists (percussion and voice) instead of one. Does it feel strange to have a piece that you thought had taken its final form go through more changes?

VAILlANCOURT. Most of Brian's chamber music was written for specific performers. The concerto is no exception. He asked me to send him a video of all my instruments so he could see and hear what they sounded like in order to choose from the collection. He transcribed all the pitches from the different sets of gongs, Noah bells, prayer bowls, wind chimes, and Burmese prayer bells. Though this makes the piece unique, it does make it very difficult to program with someone else performing the solo part, requiring major instrumental substitutions (not unlike Stockhausen's instrument collections for Kontakte, for example).

Soon after premiering and recording the piece in 2007 at CSU, I recorded, then performed, the solo version. The piece was dedicated to the memory of Brian's friend John Michielsen, whom he had known for some fifty years and who passed away in September 2006. I performed the solo version in a park in the Thousand Islands for a private audience of Mr. Michielsen's friends and family. It was a very moving and meaningful event. Birds were landing around the set-up, watching and singing during the performance, reacting to what they were hearing.

I think the addition of the vocal part really completes the piece. The poetry is now better served and brought to the foreground, greatly helping the audience process the text and its setting.

I look forward to trying a duo concert version for voice and percussion, and expect it might spark further versions. I love that the piece can keep evolving, changing, providing multiple formats for performance.

HUANG. It is very interesting to have a life-long relationship with a composer such as the one you have with Brian. You are given the opportunity to not only witness, but also to participate in the evolution of a composer's work-we have the opportunity to grow together with the composer. How has your relationship developed with Brian's music since you started working together?

VAILlanCOURT. Through all these collaborations, I have always encouraged Brian to write without setting any limitations or constraints. I do think there is a deep trust between us, a trust in each other's integrity and dedication to the collaborative process. I have performed and/or premiered eight of Brian's pieces up to now and plan to record most of his chamber works that include percussion. 


\section{Conclusion}

In the Cherney symposium, I performed Playing for Time with oboist Jacqueline Leclair and pianist Kyoko Hashimoto. This piece is essentially an homage to Mauricio Kagel, engaging in devised absurdity and abstract theatre through its confrontations between the oboist and the percussionist, and the intrusion of a pianist-both musically and theatrically. Cherney's program note sets the humorous tone that informs the performer's approach:

Playing for Time was written in January and February of 1981 especially for my brother, the Toronto oboist Lawrence Cherney. Here is what some leading thinkers and critics have said about the piece. Dr. Oskar Liebfrau, noted analyst and adventurer: "Cherney's fixation about the past suggests that his early musical training (in Toronto-nota bene!) was too strict. The tensions between the players in this piece-e.g., the "one-upmanship"obviously represent a projection of subconscious anxieties about his ability to play the piano. The ending implies, in musical terms, a journey back to the womb. A classic case." Luigi Pianissimo, music and political theorist, author of Music and Politics: A Set-Deterministic Approach: "The mere fact that so much of the pitch structure of the piece is based on set 5-1(12) (Pcs. $0,1,2,3,4)$ strongly suggests a relationship with the third of Alban Berg's Altenberg Lieder. Cherney's choice of this particular set can be justified in theory only. In fact, Playing for Time raises basic questions concerning the pitch-class struggle, which can only be resolved by throwing up the old order." Johannes Ragland, music critic and funeral parlour director: "In Playing for Time, by Montreal composer Brian Cherney, we were subjected to a seemingly endless display of tasteless humour and banal scraps which despite heroic efforts on the part of the performers, never coalesced into a convincing whole. In short, a nothing-new work." Dr. Ellen Vogelkopf, musicologist and expert in nineteenth-century ornithological etymology: "I detect an undercurrent of pessimism running through this piece, a stream of irony which broadens and sweeps all before it as the work draws to its tenuous close. Obviously the mask and the waltz music were intended to refer the listeners to Flegeljahre-why otherwise the suggestions of Schumann mixed with a little Brahms, a kind of Romantic cocktail? - but surely the music of Wagner would have provided a better vehicle through which to unleash this torrent of Spenglerism. Cherney seems to be bidding adieu to the world of yesterday. But can he successfully navigate the treacherous waters of New Music and reach The Music of the Future beckoning from distant shores?"

The piece begins with a series of bows between the oboist and the percussionist, with virtuosic passages interjected in between. Halfway through the piece, the pianist, dressed in a Victorian gown, mask, and gloves, enters the concert hall through the audience and begins to play Schumannesque passages on the piano, throwing the oboist and percussionist off their game. The execution of these gestures and their timing are essentially what makes the piece engaging. When these theatrical moves are coupled with difficult musical passages, it gives the players a lot to think about and work with. Figure 5 shows the moment in Playing for Time that leads to the breakdown of the oboist and 
percussionist. After politely bowing to each other in the first five minutes of the work, the percussionist and oboist are then engaged in a violent theatrical confrontation. The percussionist is asked to frantically place objects on the bass drum in order to drown out the oboist with increasing levels of noise. At the peak of this escalating conflict, the pianist enters the stage and changes the rules of the ongoing game. Reading the score and examining its instructions, complete with diagrams and illustrations, along with its precise notation, at times feels similar to reading the French comic Asterix - a surreal and funny voyage in and out of space and time.

Cherney uses several different styles of notation in his scores, ranging from conventional to graphic-almost like a pastiche Romantic comic book. His notation tells us a lot about his personality and artistic vision-particularly his attention to detail and his humour. Some of the notational approaches at first may seem confusing and overwhelming. For instance, in looking at the score of Tombeau, I was reminded of Evryali by Xenakis. Unlike Xenakis, Cherney's scores are almost never unplayable. However, the player has to make interpretative decisions so that one is not trapped navigating the notational maze
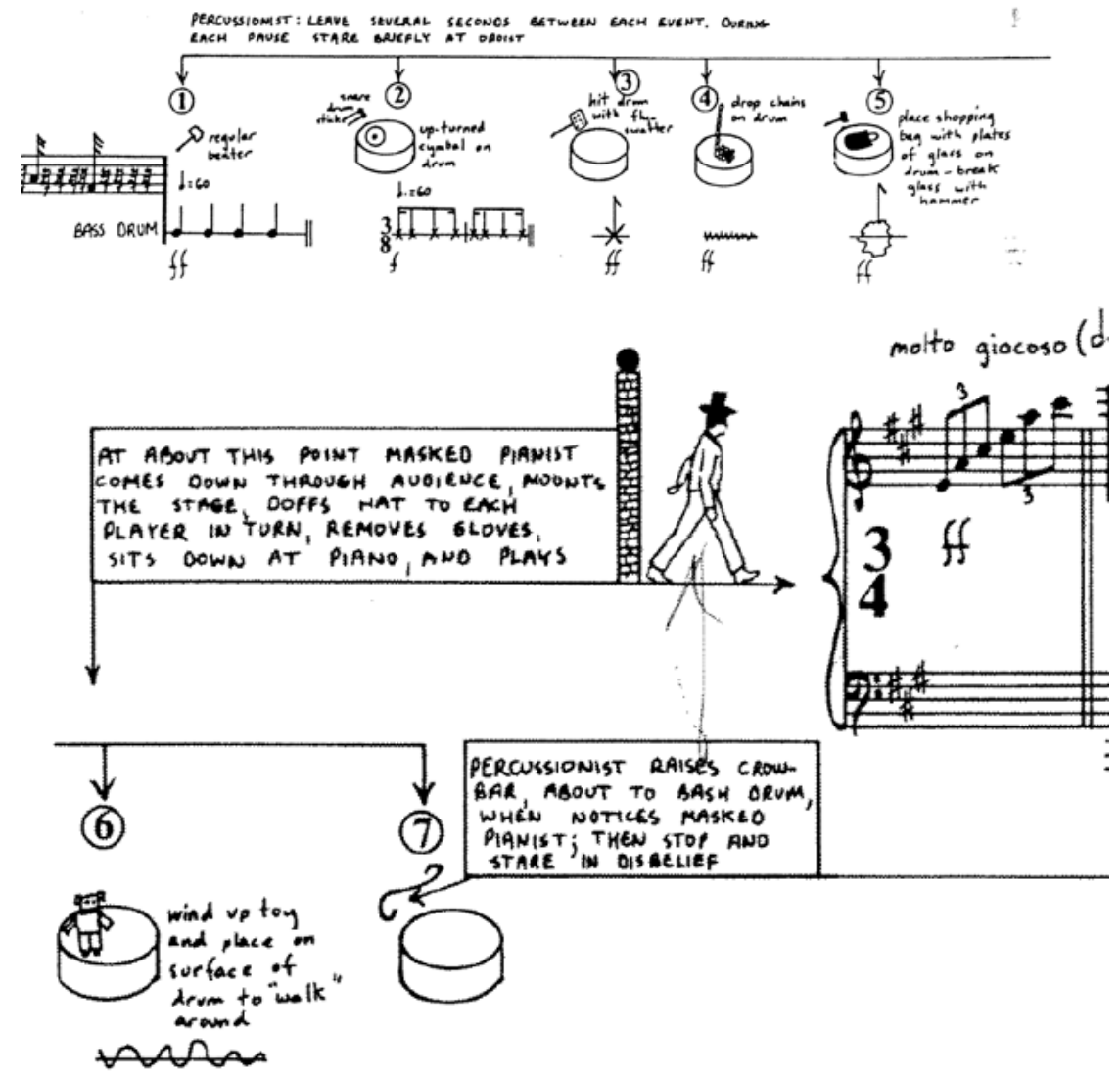

Figure 5. Playing for Time, pp. 6-7 
and is therefore available to pursue some of the more refined interior qualities commonly found in Cherney's music.

Upon first glance, performers often can have extreme reactions to his scores because of the distinctive look of the notation-although varied in style, it can come across as unfriendly upon first examination. This can lead to either an immediate turn-on or turn-off for the player. Some will see it as a provocative creative challenge, while others might see it as the work of someone who might not know how to notate economically and clearly. I have witnessed both reactions in my experiences of working on and coaching Cherney's music. For players who commit to spending a substantial amount of time with this music, the notation becomes much more than just a set of instructions. It is a display of Cherney's multifaceted way of looking at and reflecting upon the world.

When listening to Cherney's music during the symposium, I consistently heard a remarkable sense of stillness. This is also a common sentiment expressed by the interviewees. Marina Thibeault used the word heavenly and Julia Den Boer used the word ethereal. Despite the amount of dense activity on the surface of the music, deep down, I sense tranquillity-very much like the Montreal winter in January when the whole city is buried and muffled by heavy snow. The struggle of daily life becomes the surface noise and music, but deep down it is this evocative stillness of the deep winter that makes Cherney's music truly Canadian.

Cherney was born and grew up in Canada in a Jewish family. His musical education was in the European tradition. However, just as with any living Canadian artist, he cannot possibly avoid contemplating how to engage with the European tradition from a New World sensibility that is intercultural and meaningful to the world we live in. Cherney has done so successfully through his in-depth knowledge of the European tradition, his fearless ways of approaching the act of composing, and his introverted humour through notation.

\section{REFERENCES}

Cherney, Brian. 1976. String Trio. Toronto.

-1981. Playing for Time. Montreal.

. 1992. Shekhinah. Saint-Nicolas, QC: Les éditions Doberman-Yppan.

-2006. In Gottes Gärten schweigen die Engel. Montreal.

_. 2017. "Program Notes." Illuminations: Brian Cherney at 75. Montreal: McGill University.

Marrus, Michael R. 1987. The Holocaust in History. Toronto: Lester \& Orpen Dennys.

Rilke, Rainer Maria. 2009. The Poetry of Rilke, translated by Edward A. Snow. New York: North Point.

Rodal, Alti. 1988. "Finding Truth through History: The First Survey of Holocaust Historians Helps Dispel the Myths about a Horror beyond Belief." Montreal Gazette, 19 March. [Review of Marrus 1987.] 


\begin{abstract}
The composition and performance practice of the Canadian composer Brian Cherney's music is contextualized in interviews with violist Marina Thibeault, pianist Julia Den Boer, and percussionist Paul Vaillancourt. These three musicians performed major works by Cherney in "Illuminations: Brian Cherney at 75 " to celebrate the work and life of the composer. All three interviewees analyze the challenges presented by Cherney's scores and discuss the ways they found inspiration in the interpretation of the music.
\end{abstract}

\title{
RÉSUMÉ
}

La composition et l'interprétation de la musique du compositeur canadien Brian Cherney sont mises en contexte au moyen d'entrevues avec l'altiste Marina Thibeault, la pianiste Julia Den Boer et le percussionniste Paul Vaillancourt. Ces trois musiciens ont interprété des œuvres importantes de Cherney pour Illuminations: Brian Cherney at 75 visant à célébrer l'œuvre et la vie du compositeur. Ils analysent tous les trois les défis que posent les partitions de Cherney et discutent des formes d'inspiration qu'ils ont trouvées dans l'interprétation de sa musique.

\section{BIOGRAPHIES}

The French-American pianist Julia Den Boer is a strong advocate of contemporary music. Based in New York City, she performs internationally as a soloist and chamber musician and has commissioned and premiered numerous works. She is committed to exploring and pushing her instrument's boundaries through close collaboration with composers and has had the opportunity to work with some of the most prominent composers of our time, such as Heinz Holliger, Philippe Leroux, Martin Matalon, and Kaija Saariaho.

Aiyun Huang holds a DMA from the University of California, San Diego, where she taught between 2004 and 2006. Between 2006 and 2017 she led the percussion program at McGill University, transforming the studio into one of international reputation. She is an associate professor and the head of the percussion program at the University of Toronto, where she continues the legacy established by Nexus.

Marina Thibeault. Celebrated for her deep rich sound, exceptional virtuosity, and enthusiasm, violist Marina Thibeault travels the world as a sought-after recitalist, chamber musician, and soloist. She is an ardent ambassador for new music and seeks to champion diversity and innovation in the classical world. She is the recipient of numerous awards, most recently Révélations Radio-Canada 2016-17, the Sylva Gelber Foundation Award (2016), and First Prize in the string category of Prix d'Europe (2015) and the McGill Concerto Competition (2015).

Paul Vaillancourt, professor of percussion at Columbus State University, has been a featured soloist with the St. Petersburg Chamber Philharmonic, the National Arts Centre Orchestra, the Ottawa Symphony Orchestra, and at the Banff and Aspen Music Festivals. Recent concerto performances have included Michael Daugherty's Raise the Roof with the CSU Wind Ensemble, and Jennifer Higdon's Percussion 
Concerto with the CSU Philharmonic, the Guanajuato Philharmonic Orchestra in Mexico and the Thailand Philharmonic Orchestra. He is a founding member of several innovative contemporary music groups including the Furious Band, the Fountain City Ensemble, and STRIKE with pianist Jeff Meyer. STRIKE's tours of China, Russia, and Thailand included performances at the Beijing Modern Music Festival, the Central Conservatory, Tianjin Conservatory, SoundWays New Music Festival in St. Petersburg, at the Thailand International Composers Festival, and at universities in the Greater Bangkok area. 